\title{
CONTRIBUTION FIELD INDUSTRIAL PRACTICE ABOUT STUDENT WORKING READINESS OF MACHINE ENGINEERING PROGRAMS STUDENT WORKING
}

\author{
*M.Iqbal ${ }^{1}$, Jalius Jama ${ }^{2}$, Refdinal ${ }^{3}$ \\ ${ }^{1}$ Magister Student of Faculty of Engineering, Universitas Negeri Padang, Indonesia \\ ${ }^{2}$ Automotive Engineering Lecture, Faculty of Engineering, Universitas Negeri Padang, \\ Indonesia \\ ${ }^{3}$ Mechanical Engineering Lecture, Faculty of Engineering, Universitas Negeri Padang, \\ Indonesia \\ E-mail: ibalvnz@gmail.com
}

*Corresponding Author, Received: November 12, 2019, Revised: December 10, 2019, Accepted: December 21, 2019

\begin{abstract}
This research aims to explain the contribution of the readiness of student work Field Industrial practice Vocational High School 1 West Sumatra engineering expertise machining program. The method used is descriptive moetode Ex-post facto or also called measurement after the incident. Subjects in the study were 86 person who is a student of VHS 1 West Sumatra engineering expertise machining program. Data collection researchers did use a questionnaire that was distributed to the students. Field Industrial practice experience vocational students contributed $32.5 \%$ of the students' work readiness. The conclusion of this is the implementation Field Industrial practice peneltiian students of VHS 1 West Sumatra engineering expertise machining program included in both categories, and for job readiness 1 West Sumatra vocational students in the high category. This means that research subjects are students of VHS 1 West Sumatra engineering expertise machining program has a good level of job readiness.
\end{abstract}

Keywords : Field Industrial, Student Working, Student Working

\section{INTRODUCTION}

The development of industry in the era moderni world today is rapidly increasing man power are required to produce a skilled, creative, innovative and have expertise in their field. This leads to competition in the world of work is increasingly tight. A person's skills and expertise can be obtained through training or formal education. Vocational School (VHS) is one of formal education which organizes secondary education give more emphasis to the student with the skills according to the 


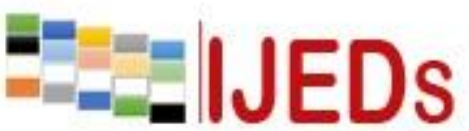

http://ijeds.ppj.unp.ac.id/index.php/IJEDS
International Journal of Educational Dynamics

Vol. 2 No. 1 (pp. 91-98) Desember 2019

p_ISSN 2655-4852

e_ISSN 2655-5093

chosen field. VHS priority to the development of students' ability to be ready to work in a particular field, the ability to adapt the work environment, employment opportunities and development see themselves in the future. In line with the aim to prepare middlelevel manpower professional, the students of vocational graduates are expected to have the readiness to enter the world of work and have the skills and attitudes of professionals in the field

Based on observationthat researchers do in VHS 1 West Sumatra through the student representative data obtained machining engineering graduates. Can be see recap of graduates in table:

Table 1.Data Graduated Students of VHS 1 West Sumatra

\begin{tabular}{|c|c|c|c|c|}
\hline Year & $\begin{array}{c}\text { Number of } \\
\text { Graduates }\end{array}$ & $\begin{array}{c}\text { Graduates } \\
\text { who work }\end{array}$ & Continue & $\begin{array}{c}\text { Not Working and } \\
\text { Everything Else }\end{array}$ \\
\hline 2017 & 141 & 33 & 53 & 65 \\
\hline 2018 & 212 & 24 & 36 & 152 \\
\hline
\end{tabular}

Source: Deputy Head and Deputy Head of Public Relations Student

Can be seen from the data obtained there are vocational school graduates who do not work. This happens because students are less prepared to enter the world of work and lack of skill. To maximize competency skillsstudents, the implementation of learning not only in school but needs to be done in the industrialized world in the form of field Industrial practice.

Field Industrial practice is done while working by using the employment situation as a place of learning. Ideally, after experiencing the learning process in schools and training process in the world of work through field Industrial practice vocational graduates will be able to become a workforce with a level of competence or a high level of work readiness. Field Industrial practice implementation is expected to add to the experience of students regarding job description in industry world. Field Industrial practice also can ease the burden of VHS, because with Field Industrial practice could student learn about the tools and the atmosphere in the industry that can not be provided by the school.Students feel is still not ready in the implementation about field Industrial practice . This is because students feel afraid to do the work provided by the company when it is in industry world. Many students prefer to doing field Industrial practice in general industry. 


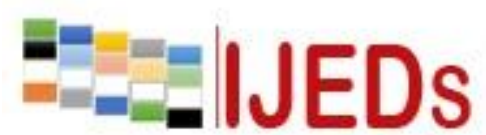

http://ijeds.ppj.unp.ac.id/index.php/IJEDS
International Journal of Educational Dynamics

Vol. 2 No. 1 (pp. 91-98) Desember 2019

p_ISSN 2655-4852

e_ISSN 2655-5093

In the implementation time given to field Industrial practice is one semester. Monitoring conducted by the supervising teacher in evaluating the practice of students during practice at less than optimal perceived as a tutor just checking students 1 month. Teachers do not know in detail what students can do while at practice. Most agencies consider vocational students have not been able to handle the job. Students are placed on many other jobs that do not correspond to their fields so that they can not apply the theory on the subject acquired in school earning their place of practice.

Based on the description the researchers felt the need to do research to determine the contribution of the industrial working practices of vocational students job readiness skills program student VHS 1 West Sumatra machining techniques. To test the truth of these allegations, the purpose of this study was to clarify how the contribution of Field Industrial practice the readiness of vocational students work one of West Sumatra.

\section{METHOD}

Methods and types of research using ex-post facto or also called measurement result after the incident with a quantitative approach. According Suharsimi Arikunto (2010: 27) is a quantitative approach to research the use of numbers, ranging from data collection, interpretation of the data, as well as the appearance of the results. The description of the data used as a reference to describe and illustrate the tendency of each variable researcher.

This study was made to explain the contribution that occur between independent variables are field Industrial practice the dependent variable is the readiness of the students' work. Where the research was VHS 1 West Sumatra. The population in this study consisted of a class XI student membership program machining techniques that have been carrying out as much field Industrial practice 86 . The sample used in this study using the technique of saturated samples. Citing the opinion Arikunto (2010), where the population is less than 100 people, then taken a whole, so that the research was population research. The instrument used in this study was a questionnaire with a scale interval of four. Before the questionnaire is distributed to first test the validity by three experts in their field. 


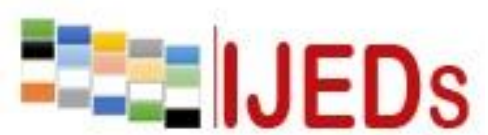

http://ijeds.ppj.unp.ac.id/index.php/IJEDS
International Journal of Educational Dynamics

Vol. 2 No. 1 (pp. 91-98) Desember 2019

p_ISSN 2655-4852

e ISSN 2655-5093

\section{RESULTS AND DISCUSSION}

Research conducted at VHS 1 West Sumatra with the subject class XI student membership programs as much machining techniques 86 . The independent variable in this study the industrial working practices $(\mathrm{X})$ and the dependent variable in this study a job readiness $(\mathrm{Y})$.

The following job readiness variable based on answers 86 respondents with 25 grains of questions shows that the highest score 73 and lowest score 52 . The analysis showed the mean price of 62.00 , the median 62.10, mode 62.10 and standart Deviasi 4,115 , Next the result distributed of obtained value 7 to number interval range Data 20 and length class 2.9. As for job readiness varabel distribution as follows:

Table 2. Variable Frequency Distribution Job Readiness

\begin{tabular}{|c|c|c|c|}
\hline No & Interval & frequency & Presentation \\
\hline 1 & $52-54,9$ & 4 & $4,65 \%$ \\
\hline 2 & $55-57,9$ & 8 & $9,30 \%$ \\
\hline 3 & $58-60,9$ & 19 & $22,09 \%$ \\
\hline 4 & $61-63,9$ & 26 & $30,23 \%$ \\
\hline 5 & $64-66,9$ & 16 & $18,60 \%$ \\
\hline 6 & $67-69,9$ & 10 & $11,36 \%$ \\
\hline 7 & $70-72,9$ & 3 & $3,49 \%$ \\
\hline \multicolumn{2}{|r|}{ Amount } & 86 & $100 \%$ \\
\hline
\end{tabular}

Based on the frequency distribution data can be described frequency like a job readiness following:

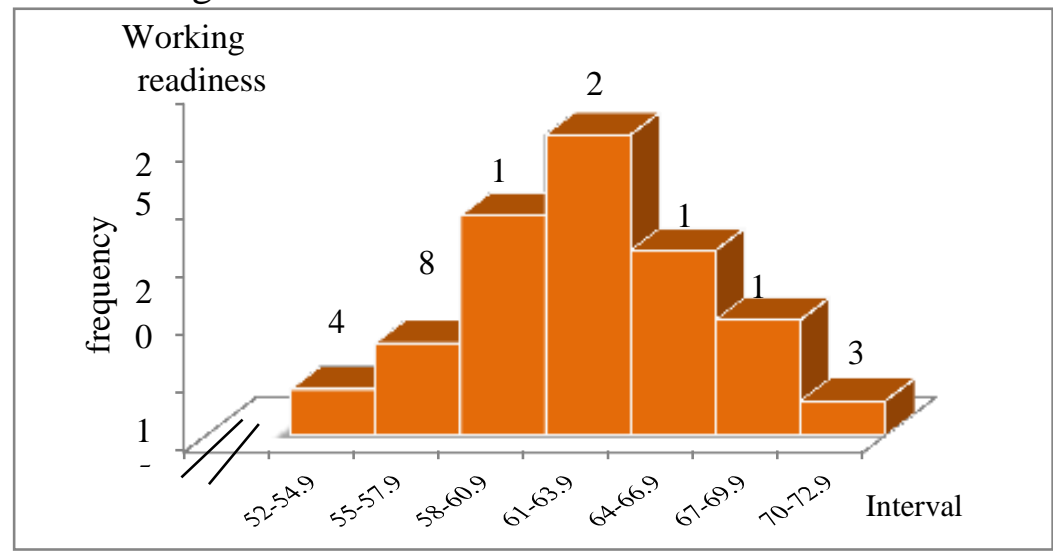

Figure 1. Histogram Variable Frequency Distribution Job Readiness

Furthermore, the identification of trends Work Readiness variables using empirical mean value and standard deviation empirical. The above calculations showed that the employment readiness of students of VHS 1 West Sumatra engineering expertise machining program in a category is. Field Industrial practice experience data 


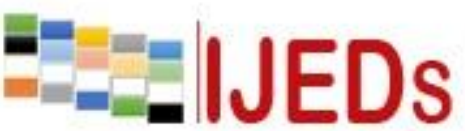

http://ijeds.ppj.unp.ac.id/index.php/IJEDS
International Journal of Educational Dynamics

Vol. 2 No. 1 (pp. 91-98) Desember 2019

p_ISSN 2655-4852

e_ISSN 2655-5093

obtained through a questionnaire of 16 items questions with four alternative answers and the number of respondents 54 students. The analysis showed prices mean 53.18, median 54.02, mode 52 and a standard deviation of 4:42. Furthermore, the results are distributed and available to class intervals of 7 to 18 and the length of the data range class 2.6. The frequency distribution varabel field Industrial practice experience as follows:

\section{Table 3. Variable Frequency Distribution Field Industrial practice experience}

\begin{tabular}{|c|c|c|c|}
\hline No & Interval & frequency & presentation \\
\hline 1 & $46-48,6$ & 14 & $16,28 \%$ \\
\hline 2 & $48,7-51,3$ & 14 & $16,28 \%$ \\
\hline 3 & $51,4-54$ & 19 & $22,09 \%$ \\
\hline 4 & $54,1-56,7$ & 17 & $19,07 \%$ \\
\hline 5 & $56,8-59,4$ & 13 & $15,12 \%$ \\
\hline 6 & $59,5-61,2$ & 7 & $8,14 \%$ \\
\hline 7 & $62,2-64,8$ & 2 & $2,33 \%$ \\
\hline \multicolumn{2}{|c|}{ Amount } & 86 & $100 \%$ \\
\hline
\end{tabular}

Based on the frequency distribution data can be described frequency seabagai job readiness following:

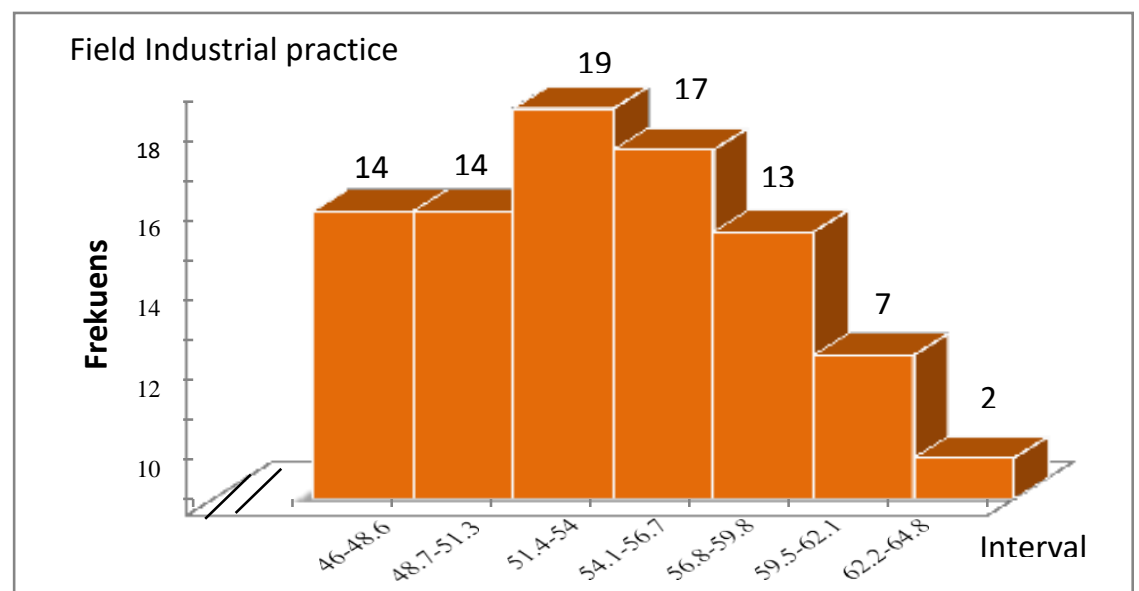

Figure 2. Histogram Variable Frequency Distribution Industry Work Practices

Furthermore, the identification of trends in the variables field Industrial practice experience using empirical mean value and standard deviation empirical. The above calculations showed that the employment readiness of students of VHS 1 West Sumatra engineering expertise machining program in the category of low group of 15 students $(17.4 \%)$, the group is as many as 58 students $(67.4 \%)$, and high groups were 13 


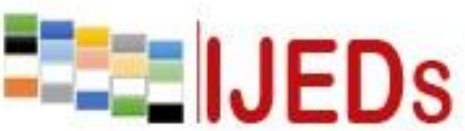

http://ijeds.ppj.unp.ac.id/index.php/IJEDS
International Journal of Educational Dynamics

Vol. 2 No. 1 (pp. 91-98) Desember 2019

p_ISSN 2655-4852

e_ISSN 2655-5093

students $(15.1 \%)$. Based on these results Field Industrial practice variable in a category is.

Linearity test is to determine how to shape the relationship between the independent variables and the dependent variable, Linearity test criteria is that the relations be linear if the value of $\mathrm{F}\left\langle\mathrm{F}_{\text {tabel }}\right.$ or significance value $>0.05$. Linearity test results in the appendix presented in the table below.Linearity test results can be seen see the significant value of track deviation from linierity. The calculation is performed with the help of PSS for Windows versi20.0.

The significance value listed in the table ANOVA Table of output generated by SPSS for Windows version 20.0. Summary linearity test results can be seen in Table 2 below.

Table 3. Summary of Linearity Test Results Variable Value Significance Description

\begin{tabular}{|l|c|l|}
\hline \multicolumn{1}{|c|}{ Variable } & Score significant & Information \\
\hline $\begin{array}{l}\text { Field Industrial practice }(\mathrm{X}) \\
\text { Working readiness }(\mathrm{Y})\end{array}$ & 0,334 & linear \\
\hline
\end{tabular}

Sources: Primary data are processed

Based on Table 2 obtained significant value in the lane deviation from linierity $>0.05$. It can be concluded that the relationship between independent variables and the dependent variable is linear.

The hypothesis is a temporary answer to the problem are formulated. This temporary answer must be empirically verifiable. Table 4 below presents a summary of the results of a simple regression analysis (XY) using SPSS for Windows version 20.0.

Table 4. Summary of the results of a simple regression analysis (XY)

\begin{tabular}{|c|c|}
\hline Variable & Coefficient \\
\hline $\mathrm{X}$ & 0,528 \\
\hline a constant & 33,632 \\
\hline $\mathrm{r}(\mathrm{xy})$ & 0,570 \\
\hline $\mathrm{r}^{2}(\mathrm{xy})$ & 0,325 \\
\hline tarithmetic & 6,354 \\
\hline ttable & 2,000 \\
\hline
\end{tabular}

Sources: Primary data are processed

From the results of hypothesis testing field Industrial practice vocational students experience one of West Sumatra machining program of technical expertise 


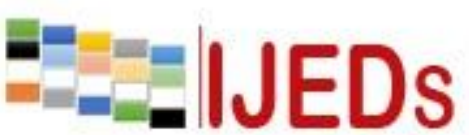

http://ijeds.ppj.unp.ac.id/index.php/IJEDS
International Journal of Educational Dynamics

Vol. 2 No. 1 (pp. 91-98) Desember 2019

p_ISSN 2655-4852

e_ISSN 2655-5093

obtained $\mathrm{t}=6.354 \mathrm{t}_{\text {table }}$ premises $\mathrm{dk}=(\mathrm{n}-2)=84$ to the rates of significant $5 \% 2,000$. Thus tarithmetic than $t_{\text {table }}(6.354>2,000)$ so that there is a contribution to the readiness Field Industrial practice work experience student of VHS 1 West Sumatra engineering expertise machining program.

\section{CONCLUSION}

Based on the results of research that has been done and diuraikan concluded THAT Field Industrial practice experience has contributed to job readiness. It can be seen from the value of $\mathrm{r} x y$ is 5.70 to 0.325 and tarithmetic determination (6.354) $>\mathrm{t}_{\text {table }}$ (2.000). With a score of 0.325 determinant may diarikan that field Industrial practice has contributed $32.5 \%$ to the job readiness of students. Meanwhile $67.5 \%$ is influenced by other factors.

On the basis of the conclusions in this research, there are some things that it feels should be done to increase job readiness on students of VHS them on students it is expected that they can follow field Industrial practice with sincerely so that after they had completed their studies feel ready to enter the world of work.

Meanwhile things that need to be improved by the teachers, the quality and quantity in monitoring the implementation of field Industrial practice by providing guidance, motivation and see how the capabilities of the students during activities Field Industrial practice .

\section{REFERENCES}

Anoraga. (2009) Psikologi Kerja.Jakarta : Rineka Cipta.

Depdiknas. (2004). Kurikulum VHS Edisi 2004. Jakarta: Depdiknas.

Erma Dwi Astuti. (2012). Pengaruh Pengalaman Praktik Kerja Industri dan Prestasi

Belajar terhadap Kesiapan Kerja Siswa Kelas XII Kompetensi keahlian Akuntansi VHS YPKK 1 Sleman Tahun Pelajaran 2011/2012. Skripsi. Pendidikan Akuntansi. FE UNY.

Herminanto Sofyan. (2000). Kesiapan Kerja STM Se-Jawa untuk Memasuki Lapangan Kerja. Yogyakarta: Jurnal Pendidikan Lembaga Penelitian IKIP Yogyakarta.

Oemar Hamalik. (2007). Pengembangan SDM Pelatihan Ketenagakerjaan Pendidikan Terpadu. Jakarta: PT Bumi Aksara.

Oemar Hamalik. (2008). Kurikulum dan Pembelajaran. Jakarta: Sinar Grafika

Rosleny, Marliani. (2015). Psikologi Industri dan Organisasi. Bandung: Pustaka Setia. 
http://ijeds.ppj.unp.ac.id/index.php/IJEDS

Vol. 2 No. 1 (pp. 91-98) Desember 2019

Singgih Santoso. (2001). SPSS Versi 10: Mengolah Data Statistik Secara Profesional. Jakarta: PT. Elex Media Komputindo.

Sugihartono, dkk. (2000). Aspirasi Siswa Terhadap Pekerjaan dan Prestasi Akademik Kaitannya dengan Kesiapan Memasuki Dunia Kerja pada Siswa Sekolah Kejuruan di Daerah Istimewa Yogyakarta. Laporan Penelitian. FIP: IKIP Yogyakarta.

Suharsimi, Arikunto. (2010). Prosedur Penelitian Suatu Pendekatan Praktik. Jakarta: Rineka Cipta

Sukardi. (2003). Metodologi Penelitian Pendidikan Kompetensi dan Prakteknya. Jakarta: Bumi Aksara.

Wibowo. (2011). Manajemen Perubahan. Jakarta: PT RajaGrafindo Persada.

Winkel, W. S. (2004). Psikologi Pendidikan dan Evaluasi Belajar. Jakarta: PT. Gramedia Pustaka Utama.

Zamzam Zawawi, firdaus (2012). Pengaruh Unit Produksi, Field Industrial practice dan Dukungan Keluarga Terhadap Kesiapan Kerja Siswa VHS. Jurnal Pendidikan Vokasi Vol. 2 No. 3 Hal. 397-409. 